\title{
17 moBile SYSTEMS DEVELOPMENT: A Literature Review
}

\author{
Jens Henrik Hosbond \\ Peter Axel Nielsen \\ Department of Computer Science \\ Aalborg University \\ Aalborg, Denmark
}

\begin{abstract}
This article reviews 105 representative contributions to the literature on mobile systems development. The contributions are categorized according to a simple conceptual framework. The framework comprises four perspectives: the requirements perspective, the technology perspective, the application perspective, and the business perspective. Our literature review shows that mobile systems development is overlooked in the current debate. From the review, we extend the traditional view on systems development to encompass mobile systems and, based on the identified perspectives, we propose core characteristics for mobile systems. We also extend the traditional focus found in systems development on processes in a development project to encompass the whole of the development company as well as interorganizational linkage between development companies. Finally, we point at research directions emerging from the review that are relevant to the field of mobile systems development.
\end{abstract}

Keywords Mobile systems development, software development, literature review, mobile requirements, mobile technology, mobile applications, mobile business

\section{INTRODUCTION}

Information systems development has been researched for decades both from the viewpoint of software engineering and the viewpoint of the information system in use 
in organizations. In this article, we address the branch of systems development dealing with developing mobile applications. The present advances in mobile technologies necessitate a rethinking of systems development for this particular domain (Krogstie et al. 2004). Traditional software engineering has much to offer mobile systems development, but the limitations caused by the uniqueness of mobile applications are not clear. The organizational approaches to information systems development or approaches directed at developing Web applications for the consumer market may also have much to offer mobile systems development, but again, these limitations are not clear.

In this paper, we review the literature on mobile systems development (i.e., the research literature that purport to address mobile systems development and mobile applications, irrespective of whether these applications are for the consumer market or for organizational purposes). We do this to sort out what characterizes mobile systems development and the contributions that have already been made in this domain.

The next section outlines our research approach. In section 3 , we present the perspectives we have found and how the literature fits into these perspectives. In the discussion in section 4, we elaborate on the structure of the research knowledge on mobile systems development and, in particular, we discuss what is unique about mobile systems development compared to traditional systems development. In section 5, we conclude the article.

\section{RESEARCH APPROACH}

Along the lines suggested by Webster and Watson (2002), we have pursued a structured approach to selecting articles and we have used a concept matrix to arrive at a conceptual structuring of the domain of mobile systems development.

\subsection{Article Selection}

We have systematically searched journal articles through the Danish Article Database Service, a portal to all major journals either published by or indexed by Wiley, Siam, Emerald, Blackwell, ACM, IEEE, Kluwer, Elsevier, Proquest, JSTOR, ArticleFirst, EBSCO, FirstSearch, or Ingenta (to name a few). We have also systematically searched conference proceedings indexed by ACM, IEEE, and AIS. We have further searched through conference proceedings on mobile systems, $\mathrm{m}$-commerce, and systems development that we otherwise came across. We have focused on contributions with title, abstract, or keywords hinting that they would be relevant for this literature review and only contributions thus relevant have been reviewed in detail. We have limited our search to contributions dated 2000 or later. In effect, contributions were included in the literature review if they satisfy two criteria:

- They mention mobile systems one way or the other in the title, abstract, or keywords.

- They are relevant for the task of development. 


\subsection{Conceptual Structuring}

The structure of the literature review in the following section was developed through a concept matrix. The conceptual structure emerges from the review. The categorization of contributions is not based on an a priori conceptualization. The firstlevel categories are the primary concern of each contribution as we assess it (e.g., a contribution on how to prototype a wireless LAN is categorized as having a primary concern for requirements). The other first-level categories that emerge from the literature are technology, application, and business. The review reveals in this way four first-level categories, thus providing four primary perspectives on mobile systems development.

At the second level, we focus on the concepts addressed in each contribution as we assess it, for example, a contribution (Pedersen and Ling 2003) within the business perspective is categorized at the second level as providing an adoption and diffusion study. The review reveals 8 second-level concepts thus providing 8 areas. The areas are modeling techniques; design studies; wireless communication; architecture; security; application; adoption and diffusion studies; and business models and strategic alliances.

\section{PERSPECTIVES}

The relevance of the different discourses within the existing research on mobility has been considered by applying a systems development lens. We end up with 105 articles revealing four perspectives (first-level categories) in total covering 8 different areas (second-level concepts) of the literature on mobile systems development. The reviewed contributions and their distribution on perspectives and areas are shown in Table 1; the numbers in brackets are the number of contributions in this area.

We suggest that the four perspectives all have a role to play or influence the practice of mobile systems development. It should be noted that in the following presentation only a representative subset of the articles are used.

\subsection{The Requirement Perspective}

The requirement perspective is here applied as a category comprising two areas within mobile systems development: (1) the literature on modeling techniques for designing architecturally sound mobile systems and (2) the large number of studies focusing on design and human-computer interaction (HCI). In mobile systems development, both research directions play an important role in getting the requirements right for mobile systems. 
Table 1. The Distribution of Papers in Each of the Perspectives and Areas

\begin{tabular}{|c|c|c|}
\hline PERSPECTIVES & AREAS & REFERENCES \\
\hline & $\begin{array}{c}\text { Modeling } \\
\text { techniques [4] }\end{array}$ & Drosos et al. 2004; Sauer 2004; Smith 2000, 2004 \\
\hline Requirements & $\begin{array}{c}\text { Design studies } \\
{[26]}\end{array}$ & $\begin{array}{l}\text { Ahlström et al. 2002; Andersson et al. 2004; } \\
\text { Andreasson et al. 2002; Brunnberg 2004; } \\
\text { Condost et al. 2002; Dahlbom and Ljungberg } \\
\text { 1998; Esbjörnsson 2001; Forsberg 2002; } \\
\text { Gallis et al. 2001; Gustavsson et al. 2001; } \\
\text { Hardless et al. 2001; Kjeldskov and Graham } \\
\text { 2003; Kjeldskov et al. 2004; Lindroth 2002; } \\
\text { Lindroth et al. 2001; Lundin and Magnusson } \\
\text { 2002; Lundin and Nuldén 2004; Messeter et } \\
\text { al. 2004; Nilsson 2001; Olsson 2004; Pareto } \\
\text { and Snis 2004; Pica 2002; Östergren 2004; } \\
\text { Smith-Berndtsson and Åström 2001; } \\
\text { Weilenman 2001; Xu and Teo 2004 } \\
\end{array}$ \\
\hline \multirow[b]{2}{*}{ Technology } & $\begin{array}{c}\text { Wireless } \\
\text { communications } \\
{[\mathbf{1 8}]}\end{array}$ & $\begin{array}{l}\text { Carneiro et al. 2004; Chen et al. 1998; Gao et } \\
\text { al. 2004; Hang et al. 1997; Hsieh and } \\
\text { Sivakumar 2004; Hu and Zhang 2004; } \\
\text { Huang and Zhuang 2004; Iraqi et al. 2000; } \\
\text { Jiang and Zhuang 2004; Kim et al. 2003; } \\
\text { Lindgren et al. 2003; Lu et al. 2004; } \\
\text { Mahadevan and Sivalingam 2001; } \\
\text { Mohapatra et al. 2003; Niebert et al. 2004; } \\
\text { Wei and Gitlin 2004; Wu and Chuang 2001 }\end{array}$ \\
\hline & Architecture [17] & $\begin{array}{l}\text { Braun et al. 2004; Bruno et al. 2001; } \\
\text { Cannataro and Pascuzzi 2001; Dahlberg et } \\
\text { al. 2001; Davies et al. 2002; Fife and } \\
\text { Gruenwald 2003; Jing et al. 1999; Karimi } \\
\text { and Krishnamurthy 2001; March et al. 2000; } \\
\text { Metafas et al. 1996; Pierre 2001; Pitoura and } \\
\text { Bhargava 1994; Sanneblad 2001; Schoeman } \\
\text { and Cloete 2003; Shih and Shim 2002; } \\
\text { Straub and Heinemann 2004; Thorstensten et } \\
\text { al. } 2004\end{array}$ \\
\hline
\end{tabular}




\begin{tabular}{|c|c|c|}
\hline PERSPECTIVES & AREAS & REFERENCES \\
\hline & $\begin{array}{c}\text { Security } \\
\text { [18] }\end{array}$ & $\begin{array}{l}\text { Bahl et al. 2002; Bierman and Cloete 2002; } \\
\text { Capra 2004; Dogac and Tumer 2002; Gupta } \\
\text { and Montenegro 1998; Køien 2004; Lange- } \\
\text { heinrich 2001; Mishra et al. 2004; Park et al. } \\
\text { 1998; Phillips et al. 2002; Ravi et al. 2004; } \\
\text { Schwiderski-Grosche and Knospe 2002; } \\
\text { Sklavos et al. 2005; Tang et al. 2003; Tang } \\
\text { and Veijalainen 2001; Wang and Pang 2003; } \\
\text { Weippl and Essmayr 2003; Yang et al. 2004 }\end{array}$ \\
\hline Application & $\begin{array}{c}\text { Application } \\
\text { [6] }\end{array}$ & $\begin{array}{l}\text { Christensen et al. 2002; Lipic and Osmano- } \\
\text { vic } 2001 \text {; Olla and Atkinson 2004; Raati- } \\
\text { kainen et al. 2002; Senn 2000; Varshney and } \\
\text { Vetter 2002; Yen and Chou 2000 }\end{array}$ \\
\hline \multirow[b]{2}{*}{ Business } & $\begin{array}{c}\text { Adoption and } \\
\text { diffusion studies } \\
\text { [7] }\end{array}$ & $\begin{array}{l}\text { Aarnio et al. 2002; Fogelgren-Pedersen } \\
\text { 2002; Ling 2000; Ioanna et al. 2004; Naruse } \\
\text { 2003; Pedersen and Ling } 2003\end{array}$ \\
\hline & $\begin{array}{l}\text { Business models } \\
\text { and strategic } \\
\text { alliances [9] }\end{array}$ & $\begin{array}{l}\text { Alphonse 2004; Barnes 2002; Haaker et al. } \\
\text { 2004; Olla and Patel 2002; Pedersen and } \\
\text { Methlie 2004; Sabat 2002; Siau et al. 2001; } \\
\text { Tsalgatidou and Pitoura 200; Van de Kar et } \\
\text { al. 2003 }\end{array}$ \\
\hline
\end{tabular}

\subsubsection{Modeling Techniques}

Because of the advances in wireless technologies, the level of complexity for the underlying system architecture rises. Furthermore, as complexity rises, time-to-market is as important as ever. This calls for a powerful modeling and design methodology ensuring robust and rapid development.

The increased complexity leads to at least four desirable capabilities within modeling and development of mobile systems: controllable abstraction, reusability, analysis of capabilities, and a high level of abstraction (Metafas et al. 1996). Considering these desired capabilities we may say that this "implies the need for an objectbased approach" (Metafas et al. 1996, p. 123). These modeling and architectural considerations seem to have been agreed upon in the later contributions within this field. Smith (2004) proposes an extension of the specification language Object- $Z$ (Smith 2000) to enable scalable and intuitive implementation of mobile applications. The Object- $Z$ specification language is an object-oriented approach. Smith $(2004$, p. 193) argues that the properties of "inheritance and polymorphism allow us to exploit commonalities in mobile systems by defining more complex models in terms of simpler ones." Similar attempts at applying object-oriented approaches to modeling of mobile systems have been proposed. Drosos et al. (2004) apply an extension of the unified modeling language (UML), namely UML-R (unified modeling language for real-time). The obvious benefit of UML is the already predominant use of UML in practice, implying that the applicability of UML must be conceived as high among designers. To test the 
applicability of UML-R, Drosos et al. evaluate a development project applying the UML-R design language. The evaluation showed a reduction in development time and the methodology also proved to be highly beneficial as a tool for abstraction when several development teams collaborated in codesign of the resulting mobile system.

\subsubsection{Design Studies}

We treat design studies and mobile HCI under the common area of design studies. The huge interest in research on design and use of mobile systems dates back to the late 1990s. Dahlbom and Ljungberg (1998) proposed mobile informatics as a new research direction within IS. The core of mobile informatics is the exploration into how mobile work may be supported by wireless technologies and how users apply these. The contributions within design studies have been many.

Another, related school of thought is the research discourse of mobile HCI. One of the research areas within mobile $\mathrm{HCI}$ shares strong relations with mobile informatics, even though the term usability test is used more frequently in mobile HCI. In mobile $\mathrm{HCI}$, there is an interest in evaluating the research approach by which evaluations of usability are carried out. Kjeldskov and Graham (2003) provide a review of the applied mobile HCI research methods. The review indicates that the laboratory testing approach dominates the mobile HCI domain even though the real-world context obviously cannot be compensated for in such settings. Consequently, they advocate for an increased interest in more context-rich research approaches (e.g., field studies or case studies). However, a recent study (Kjeldskov et al. 2004) shows that a usability test in a laboratory may be just as effective.

\subsection{The Technology Perspective}

The continuous advances of wireless technologies imply a complex and uncertain area for development companies. Developing mobile systems, therefore, necessitates in-depth analysis and consideration of what technology to use as the foundation for coming mobile systems. The technology perspective covers broadly the technical contributions adding to an increased body of knowledge on how to understand, exploit, and deal with the new technological capabilities from a technical viewpoint, and the issues and challenges emerging from these wireless innovations. Pierre (2001) contributes to the field by providing an overview of the predominant concepts and nontrivial areas (e.g., cellular systems, network infrastructure, application architecture, and security). Our literature review has revealed contributions in the three areas: wireless communications, application architecture, and security.

\subsubsection{Wireless Communications}

In this context, wireless communications covers research on or strongly related to cellular systems and network infrastructure. The increasing number of new or improved wireless network technologies is immense. The primary challenge is no longer just to go wireless, but seems to be "the ability to provide seamless and adaptive quality of 
service in such [a] heterogeneous environment" (Gao et al. 2004, p. 24). Currently, this field seems to attract particular interest both in practice and in research. Examples of some the latest contributions are a discussion of the challenges of mobile ad hoc networks (MANETs) and future directions and challenges (Mohapatra et al. 2003), a presentation of challenges and solutions in an attempt to solve the interoperability problems in the UMTS network (Kim et al. 2003; Niebert et al. 2004), a proposed a framework for integration of cellular wide wireless area networks (WWAN) and wireless local area networks (WLAN) (Wei and Gitlin 2004), and attacks on the challenges associated with turning the $4 \mathrm{G}$ platform into an open architecture including different wireless networks (Cameiro et al. 2004; Jiang and Zhuang 2004; Lu et al. 2004).

\subsubsection{Architecture}

The architecture is an essential area for development organizations. If we are developing location-based services, which imply an enormous load of requests on the underlying database management system, what architectural implications does this have? The architectural challenges have received a great deal of attention (see Davies et al. 2002; Jing et al. 1999; Pitoura and Bhargava 1994; Sanneblad 2001; Schoeman and Cloete 2003; Shih and Shim 2002). Two examples of studies in which a specific system architecture has been discussed and elaborated are Schoeman and Cloete (2003) and Shih and Shim (2002). Schoeman and Cloete discuss the architectural requirements for a mobile agent system. They contribute by developing a framework adding to an increased understanding of the architectural requirements and issues related to designing and implementing a mobile agent system. The other example represents system architectures within mobile commerce. One of the complex issues for architectures in mobile commerce is that of ensuring correct management of monetary transactions (Dogac and Tumer 2002; Shih and Shim 2002). Shih and Shim propose a scalable framework based on the Java Intelligent Network Infrastructure (JINI) capable of handling complex business transactions from a varied set of services.

\subsubsection{Security}

Another important area within mobile systems is security. Security in mobile systems exists at many levels; for example, security in wireless networks, security in embedded systems (Ravi et al. 2004), security in mobile agent systems (Bierman and Cloete 2002), security in mobile commerce systems (Schwiderski-Grosche and Knospe 2002), and security in the shape of engineering trust (Capra 2004) ensuring user integrity in mobile information sharing environment (Phillips et al. 2002). The contributions provided by this debate are of outmost relevance and importance to mobile systems development.

\subsection{The Application Perspective}

The application perspective covers articles with the aim of classifying and categorizing existing mobile applications and markets/sectors in which these may be of 
particular interest. The main contribution of this research is an increased insight into and understanding of the various classes and types of applications that exist as potential future business objects (Lipic and Osmanovic 2001; Olla and Atkinson 2004; Senn 2000). Varshney and Vetter (2002), for instance, propose a framework for classification of different types of mobile applications and end up with 10 different classes, including mobile financial applications, mobile advertising, and mobile office. Raatikainen et al. (2002) take a different path and discuss the requirements for future middleware (i.e., a set of generic services above the operating system) in order to support mobile applications. Yen and Chou (2000) take the discussion a step further and address the question of business application, managerial issues, and future developments.

\subsection{The Business Perspective}

The business perspective comprises the following two areas of research: (1) adoption and diffusion studies and (2) business models and strategic alliances. Both of these areas may play a significant role when companies consider the business potential of a mobile system. What is the potential with respect to adoption and diffusion of the product on the market? Is it necessary to initiate strategic alliances in order to ensure a solid product and minimize the costs of failure and how are such strategic alliances handled? These are just some of the questions that are relevant in the business-oriented considerations that to some extent steer and influence the development activity.

\subsubsection{Adoption and Diffusion Studies}

Adoption and diffusion studies, in general, constitute a broad research area. In recent years, there has been an interest in applying models from this research discourse on the area of m-commerce (see Aarnio et al. 2002; Fogelgren-Pedersen 2002; Han 2002; Ling 2000; Naruse 2003). The studies are broadly categorized as either diffusion studies, adoption studies, or domestication studies (Pedersen and Ling 2003). In diffusion studies, the focal point is how adoption of, for example, mobile systems takes place at the macro level (Pedersen and Ling 2003). That is, how segments or groups of endusers adopt technology. Adoption studies represent a more individualized focus and are interested in the adoption at the micro level, for instance, individual user adoption (Pedersen and Ling 2003). In the last category, domestication studies, the focus is on the use of technology and its socio-technical consequences. The focus on socio-technical issues associated with technology use is not limited to either defined end-user groups or individual users (Pedersen and Ling 2003). Domestication studies are, therefore, not limited to either a macro or micro level focus. In this way, domestication studies of endusers' habits and use patterns share concerns with design studies (section 3.1).

\subsubsection{Business Models and Strategic Alliances}

In an environment characterized by much uncertainty, such as the mobile industry, there has been a trend toward strategic alliances also refereed to as value chains (Barnes 2002; Haaker et al. 2004; Kar et al. 2003; More and McGrath 1999; Pedersen and 
Methlie 2004; Sabat 2002; Tsalgatidou and Pitoura 2001). The emergence and organization of such interorganizational networks requires that "multiple actors have to balance different design requirements, strategic requirements, and business logics to create a win-win situation, in which each actor has an incentive to cooperate" (Haaker et al. 2004, p. 1). Actors in these networks may be technology platform vendors, network and infrastructure vendors, application developers, or content providers (Sabat 2002; Tsalgatidou and Pitoura 2001).

In a case study of the business model applied in the design and launch of i-mode's ringtunes service, Kar et al. (2003) propose four elements that together represent the business model for the ringtunes service concept. The four elements are (1) service formula, (2) network formation and coordination, (3) enabling technology, and (4) revenue model. The literature within mobile commerce seems to agree largely on these dimensions as constituting elements of a business model (see Haaker et al. 2004; Pedersen and Methlie 2004). According to Kar et al., the service formula is concerned with defining the service strategy for adding value to the end-customer (e.g., what and how content is to be offered). The network formation and coordination--or the governance dimension (Pedersen and Methlie 2004) defines the rules of engagement in the interorganizational alliance. Finally, Kar et al. emphasize the importance of getting the technological issues solved and reaching, for all parties, an acceptable revenue model.

\section{DISCUSSION}

The literature review reveals the current state of the mobility debate and also its contribution to mobile systems development. The distribution of the reviewed articles on the different perspectives is depicted in Figure 1.
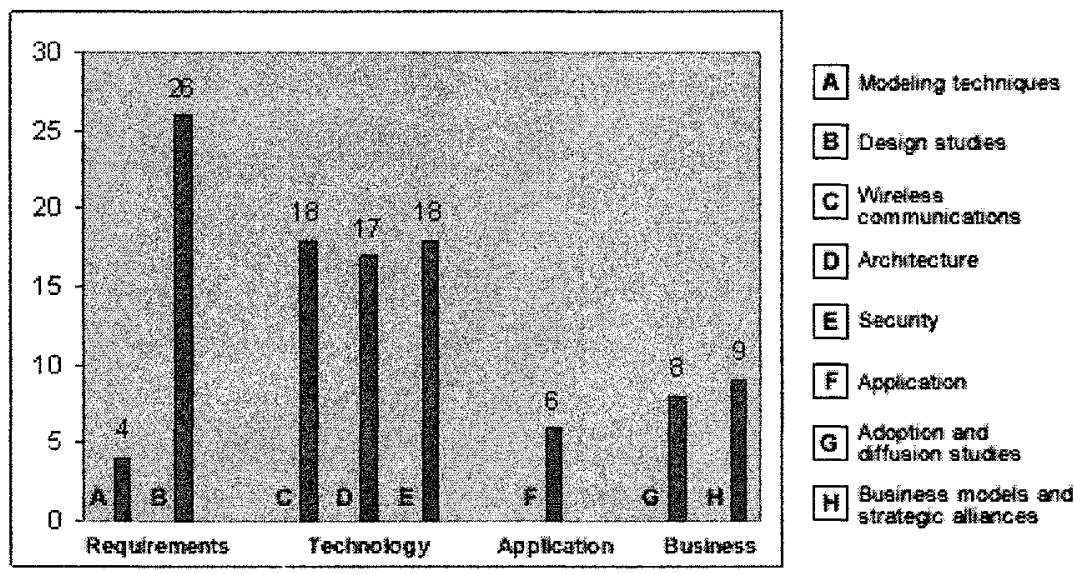

Figure 1. Histogram of the Different Perspectives and the Distribution of Articles 
Interpreting the distribution of contributions brings forth several issues. Clearly, the distribution shows an overweight of technology-related contributions. The three areas within the technology perspective represent 50 percent (53 papers out of 105) of the articles in this review. Arguably, we may say that the mobility debate so far has been largely technology-driven. The strong focus on technology is an obvious indicator of continuous development and innovation within this field, which reflects somewhat immature technologies, but also emphasizes a strong demand for more robust and flexible mobile technologies.

The requirements perspective shows an uneven distribution between the two areas (modeling techniques and design studies; see Table 1). Modeling techniques are covered in only four articles whereas design studies are covered in 26 articles. Both areas are important in a mobile systems development context when trying to understand the requirements. However, the current state of the research literature reveals that much needs to be done in the area of modeling techniques in order to develop a sufficient body of knowledge of how to actually model these systems. The role of modeling techniques should not be underemphasized as these contributions are necessary as a first step toward conceptualizing mobile systems from a development perspective. In a discussion of the characteristics of mobile systems, Krogstie et al. (2004) propose model-based techniques as a way forward to understand the particularities of these systems. In general, the implications of mobility have been extensively studied, taking many different perspectives. The varying types of contributions may all have a role to play in mobile systems development, but the limitations are unclear. As a first step, we propose an extension of the scope of traditional systems development that may contribute to a framing of mobile systems development.

The literature review shows that the scope of mobile systems development is an extension of the scope of traditional systems development.

From the literature on mobile systems development, it is easy to get the impression that all that has been learned and written about traditional systems development is neglected as it is hardly mentioned in the literature we have reviewed. It is, however, necessary to look at the recent research on mobile systems development as an extension of the existing body of knowledge on systems development (see Figure 2).

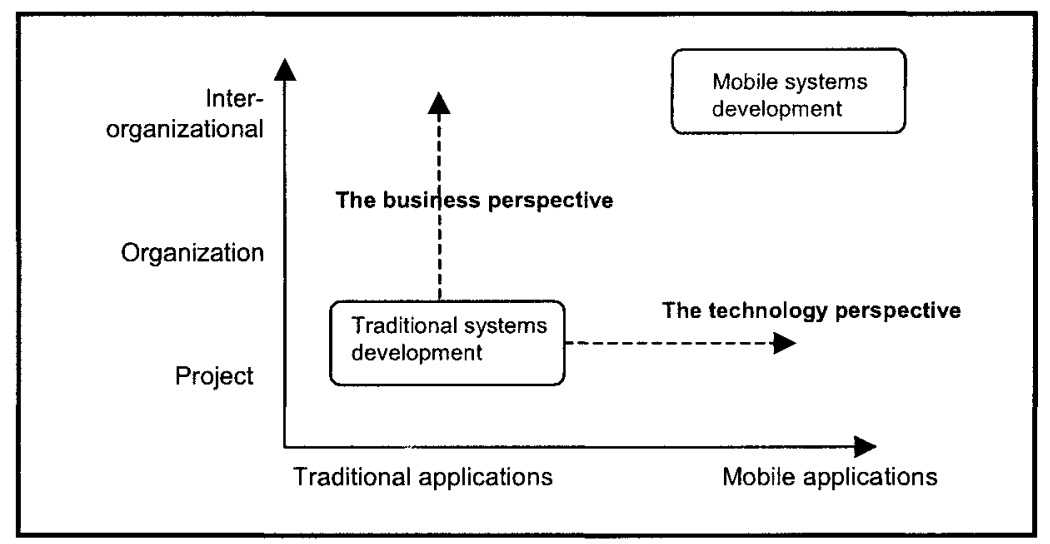

Figure 2. The Extended Scope of Mobile Systems Development 
Traditional systems development tends to focus on methodologies and techniques that are focusing on stationary information systems in organizations, enterprise resource planning systems, and, lately, Web information systems. The particulars of the mobile technologies as outlined in the technology perspective (section 3.2) extend the scope (horizontally in Figure 2) because of the focus on mobile wireless communications, application architectures, and security. The technology perspective has immediate implications for the requirements perspective (section 3.1) as that is directed at modeling techniques and design studies. It is striking that very little research has been directed at establishing requirements that do not merely reflect the mobile technologies, but also the organizational and social context of mobility. The technology perspective has also immediate implications for the application perspective (section 3.3) with its outline of the different types of mobile applications and their uniqueness.

Traditional systems development tends to focus primarily on the task of development at the level of the project and very little on the task of development at the level of the company or at the level of inter-organizational development. The tremendous focus within mobile systems development on the business perspective extends the scope toward higher organizational levels (vertically in Figure 2).

Business models and strategic alliances have been of some concern in traditional systems development. The increasing complexity of the task of developing mobile systems and its character in terms of both task uncertainty and business risks makes it less likely that these complexities can be handled at the level of the development project. Mobile systems development thus often involves several development projects in several development companies. Collaboration between some of these is then organized in strategic alliances (Haaker et al. 2004). Hence, the concern for strategic alliances becomes crucial in mobile systems development. Strategic alliances are not new to systems development, but seem to be more common among mobile development companies, although so far there is little research documenting this.

The increased technical complexity in mobile systems and the increased complexity of business models may well lead companies to enter into strategic alliances. Strategic alliances, on the other hand, do not reduce the complexities per se. The partakers in the alliance exercise specialization of development capabilities and competencies as well as specialization of system components or provided services. Effectively, that can increase the process complexities, as the complexity of the added collaboration also needs to be handled.

We propose that strategic alliances stand out as a unique characteristic of mobile systems development and thus deserve further attention in the pursuit of framing and understanding the implications of this concept.

\section{CONCLUSION}

In this paper, we have reviewed 106 papers and their contributions to mobile systems development. The review shows that the field is still at an early stage.

We found that little research addresses mobile systems development directly. The reviewed literature is relevant to mobile systems development, but not central. Traditional systems development may have much to offer, but is largely directed at the project level. The technological challenges in mobile systems development are signi- 
ficant, but research in these areas is not well connected to the development tasks. Strategic alliances and interorganizational development surface as one of the characteristics of mobile systems development, but remain a significant challenge for future research.

Effectively, we propose to view mobile systems development as an extension of traditional systems to encompass these new challenges.

Further research is needed in order to understand the implications of the technological challenges and challenges stemming from business models and strategic alliances on mobile systems development.

\section{REFERENCES}

Aarnio, A., Enkenberg, A., Heikkilä, J., and Hirvola, S. "Adoption and Use of Mobile Services: Empirical Evidence from a Finnish Survey," in Proceedings of the $35^{\text {th }}$ Hawaii International Conference on System Sciences, Los Alamitos, CA: IEEE Computer Society Press, 2002, pp. 1097-1106.

Ahlström, P., Berg, M., and Winberg, A. "Stationary Mobility: Designing for Train Travellers." in Proceedings of the $25^{\text {th }}$ Conference on Information Systems Research in Scandinavia, $\mathrm{K}$. Bødker, M. K. Pedersen, J. Nørbjerg, J. Simonsen, and M. T. Vendelø (Eds.), Bautahöj, Denmark, August 10-13, 2002.

Alphonse, J. "Re-creating the Norwegian Model for Selling Mobile Content in Malaysia," in Proceedings of the $27^{\text {th }}$ Conference on Information Systems Research in Scandinavia, $\mathrm{P}$. Flensburg and C. Ihlström (Eds.), Falkenberg, Sweden, August 14-17, 2004.

Andersson, M., Wridell, Y., and Lindgren, Y. "A Qualitative Interview Study Investigating the Role of Transport Information Systems in Road Haulage Firms," in Proceedings of the $27^{\text {th }}$ Conference on Information Systems Research in Scandinavia, P. Flensburg and C. Ihlström (Eds.), Falkenberg, Sweden, August 14-17, 2004.

Andreasson, N., Axelsson, J., and Kuschel, J. "Sharing of Mobile Tools: An Ethnographic Workplace Study in a Car Repair Shop," in Proceedings of the $25^{\text {th }}$ Conference on Information Systems Research in Scandinavia, K. Bødker, M. K. Pedersen, J. Nørbjerg, J. Simonsen, and M. T. Vendelø (Eds.), Bautahöj, Denmark, August 10-13, 2002.

Bahl, P., Russel, W., Wang, Y., Balachandran, A., Voelkner, G., and Miu, A. "PAWNs: Satisfying the Need for Ubiquitous Secure Connectivity and Location Services," IEEE Wireless Communications (9:1), 2002, pp. 40.48.

Barnes, S. J. "The Mobile Commerce Value Chain: Analysis and Future Developments," International Journal of Information Management (22:2), 2002, pp. 91-108.

Bierman, E., and Cloete, E. "Classification of Malicious Host Threats in Mobile Agent Computing," in Proceedings of the Annual Conference of the South African Institute of Computer Scientists and Information Technologies, Port Elizabeth, South Africa, September 16-18, 2002, pp. 141-148.

Braun, P., Müller, I., Geisenhainer, S., Schau, V., and Rossak, W. "A Service-Oriented Software Architecture for Mobile Agent Toolkits," in Proceedings of the $11^{\text {th }}$ IEEE International Conference and Workshop on the Engineering of Computer-Based Systems, Brno, Czech Republic, May 24-27, 2004, pp. 550-556.

Brunnberg, L. "The Road Rager- Making Use of Traffic Encounters in a Mobile Multiplayer Game," in Proceedings of the $27^{\text {th }}$ Conference on Information Systems Research in Scandinavia, P. Flensburg and C. Ihlström (Eds.), Falkenberg, Sweden, August 14-17, 2004. 
Bruno, R., Conti, M., and Gregori, E. "WLAN Technologies for Mobile Ad Hoc Networks," in Proceedings of the $34^{\text {th }}$ Hawaii International Conference on System Sciences, Los Alamitos, CA: IEEE Computer Society Press, 2001, p. 11.

Cannataro, M., and Pascuzzi, D. "A Component-Based Architecture for the Development and Deployment of WAP-Compliant Transactional Services," in Proceedings of the $34^{\text {th }}$ Hawail International Conference on System, Los Alamitos, CA: IEEE Computer Society Press, 2001.

Capra, L. "Engineering Human Trust in Mobile System Collaborations," in Proceedings of the $12^{\text {th }}$ ACM SIGSOFT: International Symposium on Foundations of Software Engineering, New York: ACM Press, 2004, pp. 107-116.

Carneiro, G., Ruela, J., and Ricardo, M. "Cross-Layer Design in $4 \mathrm{G}$ Wireless Terminals," IEEE Wireless Communications (11:2), 2004, pp. 7-13.

Chen, J., Sivalingam, K. M., and Acharya, R. "Comparative Analysis of Wireless ATM Channel Access Protocols Supporting Multimedia Traffic," Mobile Networks and Applications (3:3), 1998, pp. 293-306.

Condos, C., James, A., Every, P., and Simpson, T. "Ten Usability Principles for the Development of Effective WAP and m-commerce Services," Aslib Proceedings (54:6), 2002, pp. 345-355.

Dahlberg, B., Ljungberg, F., and Sanneblad, J. "Proxy Lady," Scandinavian Journal of Information Systems (14:1), 2002, pp. 3-17.

Dahlbom, B., and Ljungberg, F. "Mobile Informatics," Scandinavian Journal of Information Systems (10:1-2), 1998, pp. 227-234.

Davies, N., Cheverst, K., Friday, A., and Mitchell, K. "Future Wireless Applications for a Networked City: Services for Visitors and Residents," IEEE Wireless Communications (9:1), 2002, pp. 8-16.

Dogac, A., and Tumer, A. "Issues in Mobile Electronic Commerce," Journal of Database Management (13:1), 2002, pp. 36-42.

Drosos, C., Metafas, D., and Papadopoulos, G. "A UML-Based Methodology for the System Design of a Wireless LAN Prototype," in Proceedings of the $7^{\text {th }}$ IEEE International Symposium on Object-Oriented Real-Time Distributed Computing, IEEE Computer Society, Vienna, Austria, 2004, pp. 45-51.

Esbjörnsson, M. "Work in Motion: Interpretation of Defects along the Roads," in Proceedings of the $24^{\text {th }}$ Conference on Information Systems Research in Scandinavia, S. Bjørnestad, R. E. Moe, A. I. Mørch, and A. L. Opdahl (Eds.), Bergen, Norway, August 11-14, 2001, pp. 413-426.

Fife, L. D., and Gruenwald, L. "Research Issues for Data Communication in Mobile Ad Hoc Network Database Systems," SIGMOD Record (32:2), 2003, pp. 42-47.

Fogelgren-Pedersen, A. "Factors Promoting the Adoption of the Mobile Internet," in Proceedings of the $25^{\text {th }}$ Conference on Information Systems Research in Scandinavia, $\mathrm{K}$. Bødker, M. K. Pedersen, J. Nørbjerg, J. Simonsen, and M. T. Vendelø (Eds.), Bautahöj, Denmark, August 10-13, 2002.

Forsberg, K. "Task-in-Content: Supporting Mobile News Journalism," in Proceedings of the $25^{\text {th }}$ Conference on Information Systems Research in Scandinavia, K. Bødker, M. K. Pedersen, J. Nørbjerg, J. Simonsen, and M. T. Vendelø (Eds.), Bautahöj, Denmark, August 10-13, 2002.

Gallis, H., Kasbo, J. P., and Herstad, J. "The Multidevice Paradigm in Knowmobile" Does One Size Fit All?," in Proceedings of the $24^{\text {th }}$ Conference on Information Systems Research in Scandinavia, S. Bjørnestad, R. E. Moe, A. I. Mørch, and A. L. Opdahl (Eds.), Bergen, Norway, August 11-14, 2001, pp. 491-504.

Gao, X., Wu, G., and Miki, T. "End-to-End QoS Provisioning in Mobile Heterogeneous Networks," IEEE Wireless Communications (11:3), 2004, pp. 24-34. 
Gupta, V., and Montenegro, G. "Secure and Mobile Networking," Mobile Networks and Applications (3:4), 1998, pp. 381-390.

Gustavsson, P., Lundin, J., and Nuldén, U. "Mobile Scenarios: Supporting Collaborative Learning among Mobile People," in Proceedings of the $24^{\text {th }}$ Conference on Information Systems Research in Scandinavia, S. Bjørnestad, R. E. Moe, A. I. Mørch, and A. L. Opdahl (Eds.),, Bergen, Norway, August 11-14, 2001, pp. 59-72.

Haaker, T., Bouwman, H., and Faber, E. "Customer and Network Value of Mobile Services: Balancing Requirements and Strategic Interests," in Proceedings of the $25^{\text {th }}$ International Conference on Information Systems, R. Agarwal, L. Kirsch, and J. I. DeGross (Eds.), Washington, DC, December 12-15, 2004, pp. 1-14.

Han, S. "A Framework for Understanding Adoption and Diffusion Processes for Mobile Commerce Products and Services and its Potential Implications for Planning Industry Foresight," in Proceedings of the $25^{\text {th }}$ Conference on Information Systems Research in Scandinavia, K. Bødker, M. K. Pedersen, J. Nørbjerg, J. Simonsen, and M. T. Vendelø (Eds.), Bautahöj, Denmark, August 10-13, 2002.

Hang, L., Hairuo, M., Magda, E., and Sanjay, G. "Error Control Schemes for Networks: An Overview," Mobile Networks and Applications (2:2), 1997, pp. 167-182.

Hardless, C., Lundin, J., and Nuldén, U. "Mobile Competence Development for Nomads," in Proceedings of the $34^{\text {th }}$ Hawail International Conference on Systems Sciences, Los Alamitos, CA: IEEE Computer Society Press, 2001, p. 1048.

Hsieh, H., and Sivakumar, R. "On Using Peer-to-Peer Communication in Cellular Wireless Data Networks," IEEE Transactions on Mobile Computing (3:1), 2004, pp. 57-72.

$\mathrm{Hu}, \mathrm{M}$., and Zhang, J. "Opportunistic Multi-Access: Multiuser Diversity, Relay-Aided Opportunistic Scheduling, and Traffic-Aided Smooth Admission Control," Mobile Networks and Applications (9:4), 2004, pp. 435-444.

Huang, V., and Zhuang, W. "QoS-Oriented Packet Scheduling for Wireless Multimedia CDMA Communications," IEEE Transactions on Mobile Computing (3:1), 2004, pp. 73-85.

Ioanna, C., Damsgaard, J., and Knutsen, L. "Investigating Mobile Services Adoption and Diffusion in the Danish Market," in Proceedings of the $27^{\text {th }}$ Conference on Information Systems Research in Scandinavia, P. Flensburg and C. Ihlström (Eds.), Falkenberg, Sweden, August 14-17, 2004.

Iraqi, Y., Boutaba, R., and Leon-Garci, A. "QoS Control in Wireless ATM," Mobile Networks and Applications (5:2), 2000, pp. 137-145.

Jiang, H., and Zhuang, W. "Quality-of-Service Provisioning in Future 4G Cellular Networks," IEEE Wireless Communications (11:2), 2004, pp. 48-54.

Jing, J., Helal, A. S., and Elmargarmid, A. "Client-Server Computing in Mobile Environments," ACM Computing Surveys (31:2), 1999, pp. 117-157.

Karimi, H. A., and Krishnamurthy, P. "Real-Time Routing in Mobile Networks Using GPS and GSI Techniques," in Proceedings of the $34^{\text {th }}$ Annual Hawaii International Conference on System Sciences, Los Alamitos, CA: IEEE Computer Society, 2001, p. 11.

Kim, S., Cho, H., Hahm, H., Lee, S., and Lee, M. S. "Interoperability between UMTS and CDMA2000 Networks," IEEE Wireless Communications (10:1), 2003, pp. 22-28.

Kjeldskov, J., and Graham, C. "A Review of Mobile HCI Research Methods," in Proceedings of the $5^{\text {th }}$ International Mobile HCI Conference, L. Chittaro (Ed.), Udine, Italy, September 8-11, 2003, pp. 317-335.

Kjeldskov, J., Skov, M. B., Als, B. S., and Høegh, R. T. "Is it Worth the Hassle? Exploring the Added Value of Evaluating the Usability of Context-Aware Mobile Systems in the Field," in Froceedings of the $6^{\text {th }}$ International Mobile HCI Conference, M. D. S. Brewster (Ed.), Galsgow, September 13-16, 2004, pp. 51-73.

Krogstie, J., Lyytinen, K., Opdahl, A. L., Pernici, B., Siau, K., and Smolander, K. "Research Areas and Challenges for Mobile Information Systems," International Journal of Mobile Communications (2:3), 2004, pp. 220-234. 
Køien, G. M. "An Introduction to Access Security in UMTS," IEEE Wireless Communications (11:1), 2004, pp. 8-18.

Langeheinrich, M. "Privacy by Design: Principles of Privacy Aware Ubiquitous Systems," in

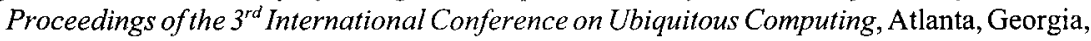
2001, pp. 273-291.

Lindgren, A., Almquist, A., and Schelen, O. "Quality of Service Schemes for IEEE 802.11 Wireless LANs: An Evaluation," Mobile Networks and Applications (8:3), 2003, pp. 223235.

Lindroth, T. "Action, Place and Nomadic Behavior-A Study Towards Enhanced Situated Computing," in Proceedings of the $25^{\text {th }}$ Conference on Information Systems Research in Scandinavia, K. Bødker, M. K. Pedersen, J. Nørbjerg, J. Simonsen, and M. T. Vendelø (Eds.), Bautahöj, Denmark, August 10-13, 2002.

Lindroth, T., Nilsson, S., and Rasmussen, P. "Mobile Usability: Rigor Meets Relevance When Usability Goes Mobile," in Proceedings of the $24^{\text {th }}$ Conference on Information Systems Research in Scandinavia, S. Bjørnestad, R. E. Moe, A. I. Mørch, and A. L. Opdahl (Eds.), Bergen, Norway, August 11-14, 2001, pp. 641-654.

Ling, R. "'We Will Be Reached': The Use of Mobile Telephony Among Norwegian Youth," Information Technology and People (13:2), 2000, pp. 102-120.

Lipic, V., and Osmanovic, A. "The Power of mPeople-Mobile Customers: What Do They Really Want," in Proceedings of the $24^{\text {th }}$ Conference on Information Systems Research in Scandinavia, S. Bjørnestad, R. E. Moe, A. I. Mørch, and A. L. Opdahl (Eds.), Bergen, Norway, August 11-14, 2001, 24, 2001, pp. 305-318.

Lu, W. W., Walke, B. H., and Shen, X. "4G Mobile Communications: Toward an Open Wireless Architecture," IEEE Wireless Communications (11:2), 2004, pp. 4-6.

Lundin, J., and Magnusson, M. "Sharing Best Practices among Mobile Workers," in Proceedings of the $24^{\text {th }}$ Conference on Information Systems Research in Scandinavia, S. Bjørnestad, R. E. Moe, A. I. Mørch, and A. L. Opdahl (Eds.), Bergen, Norway, August 11-14, 2001.

Lundin, J., and Nuldén, U. "Supporting Workplace Learning for Police Officers Finding Guidance for Design in a Mobile Work Practice," in Proceedings of the $27^{\text {th }}$ Information Systems Research Seminar in Scandinavia, P. Flensburg and C. Ihlström (Eds.), Falkenberg, Sweden, August 14-17, 2004.

Mahadevan, I., and Sivalingam, K. "Architecture and Experimental Framework for Supporting QoS in Wireless Networks Using Differentiated Services," Mobile Networks and Applications (6:4), 2001, pp. 385-395.

March, S., Hevner, A., and Ram, S. "Research Commentary: An Agenda for Information Technology Research in Heterogeneous and Distributed Environments," Information Systems Research (11:4), 2000, pp. 327-347.

Messeter, J., Brandt, E., Halse, J., and Johansson, M. "Contextualizing Mobile IT," in Proceedings of the Conference on Designing Interactive Systems, New York: ACM Press, 2004, pp. 27-36.

Metafas, D., Karathanasis, H. C., and Blionas, S. V. "Industrial Approach in Design Methodologies for Mobile Communication Systems," in Proceedings of the $7^{\text {th }}$ IEEE International Workshop on Rapid System Prototyping, Thessaloniki, Greece, June 19-21, 1996, pp. 122126.

Mishra, A., Nadkarni, K., Patcha, A., and Tech, V. "Intrusion Detection in Wireless Ad Hoc Networks," IEEE Wireless Communications (11:1), 2004, pp. 48-60.

Mohapatra, P., Li, J., and Gui, C. "QoS in Mobile Ad Hoc Networks," IEEE Wireless Communications (10:3), 2003, pp. 44-52.

More, E., and McGrath, M. "Working Cooperatively in an Age of Deregulation: Strategic Alliances in Australia's Telecommunication Sector," The Journal of Management Development (18:3), 1999, pp. 227-254. 
Naruse, K. "The Survey of the Mobile Internet, Usage, Awareness, Study for M-Commerce," in Proceedings of the 2003 Symposium on Applications and the Internet Workshops, Orlando, FL, 2003, pp. 127-130.

Niebert, N., Schieder, A., Abrahamowicz, H., Malmgren, G., Sachs, J., Horn, U., Prehofer, C., and Karl, H. "Ambient Networks: An Architecture For Communication Networks Beyond 3G," IEEE Wireless Communications (11:3), 2004, pp. 14-22.

Nilsson, V. "Method for Researching Different Abilities by Mobility," in Proceedings of the $24^{\text {th }}$ Conference on Information Systems Research in Scandinavia, S. Bjørnestad, R. E. Moe, A. I. Mørch, and A. L. Opdahl (Eds.), Bergen, Norway, August 11-14, 2001, 24, 2001, pp. 669680.

Olla, P., and Atkinson, C. "Developing a Wireless Reference Model for Interpreting Complexity in Wireless Projects," Industrial Management \& Data Systems (104:3), 2004, pp. 262-272.

Olla, P., and Patel, N. V. "A Value Chain Model for Mobile Data Service Providers," Telecommunications Policy (26:9), 2002, pp. 551-571.

Olsson, C. M. "Exploring the Impact of a Context-Aware Application for In-Car Use," in Proceedings of the $25^{\text {th }}$ International Conference on Information Systems, R. Agarwal, L. Kirsch, and J. I. DeGross (Eds.), Washington, DC, December 12-15, 2004, pp. 129-140.

Östergren, M. "Implications of Speed Trap Services for Designing Roadside-LocationDependent Messengers," in Proceedings of the $27^{\text {th }}$ Conference on Information Systems Research in Scandinavia, P. Flensburg and C. Ihlström (Eds.), Falkenberg, Sweden, August 14-17, 2004.

Pareto, L., and Snis, U. L. "Work-Integrated Mobile Technology: Towards a Patient-Oriented Workplace in Health Care Settings," in Proceedings of the $27^{\text {th }}$ Information Systems Research Seminar in Scandinavia, P. Flensburg and C. Ihlström (Eds.), Falkenberg, Sweden, August 14-17, 2004.

Park, S. H., Ganz, A., and Ganz, Z. "Security Protocol for IEEE 802.11 Wireless Local Area Network," Mobile Networks and Applications (3:3), 1998, pp. 237-246.

Pedersen, P. E., and Ling, R. "Modifying Adoption Research for Mobile Internet Service Adoption: Cross-Disciplinary Interactions," in Proceedings of the $36^{\text {th }}$ Hawaii International Conference on System Sciences, Los Alamitos, CA: IEEE Computer Society Press, 2003.

Pedersen, P. E., and Methlie, L. B. "Exploring the Relationship between Mobile Data Services, Business Models and End-User Adoption," paper presented at the $4^{\text {th }}$ IFIP Conference on eCommerce, e-Business, and e-Government, Toulouse, France, August 22-27, 2004, pp. 1-29.

Phillips, C. E., Ting, T. C., and Demurjian, S. A. "Information Sharing and Security in Dynamic Coalitions," in Proceedings of the $7^{\text {th }}$ ACM Symposium on Access Control Model sand Technologies, Monterey, CA, 2002, pp. 87-96.

Pica, D. "Location in Mobile Informatics: The Concept of 'Nomadic Reality' in Design," in Proceedings of the $25^{\text {th }}$ Conference on Information Systems Research in Scandinavia, $\mathrm{K}$. Bødker, M. K. Pedersen, J. Nørbjerg, J. Simonsen, and M. T. Vendelø (Eds.), Bautahöj, Denmark, August 10-13, 2002.

Pierre, S. "Mobile Computing and Ubiquitous Networking: Concepts, Technologies and Challenges," Telematics and Informatics (18), 2001, pp. 109-131.

Pitoura, E., and Bhargava, B. "Building Information Systems for Mobile Environments," in Proceedings of the $3^{\text {rd }}$ International Conference on Information and Knowledge Management, Gaithersburg, MD, November 29-December 2,1994, pp. 371-378.

Ravi, S., Raghunathan, A., Kocher, P., and Hattangady, S. "Security in Embedded Systems: Design Challenges," ACM Trinsactions on Embedded Computing Systems (3:3), 2004, pp. 461-491.

Raatikainen, K., Christensen, H. B., and Nakajima, T. "Application Requirements for Middleware for Mobile and Pervasive Systems," Mobile Computing and Communications Review (6:4), 2002, pp. 16-24. 
Sabat, H. K. "The Evolving Mobile Wireless Value Chain and Market Structure," Telecommunications Policy (26), 2002, pp. 505-535.

Sanneblad, J. "BluePortal: A Framework for Mobile Ad Hoc Network Applications," in Proceedings of the $24^{\text {th }}$ Conference on Information Systems Research in Scandinavia, S. Bjørnestad, R. E. Moe, A. I. Mørch, and A. L. Opdahl (Eds.), Bergen, Norway, August 1114, 2001, pp. 569-582.

Sauer, J. "Development of Mobile Applications Based on the Tools \& Materials Approach," in Proceedings of the $27^{\text {th }}$ Information Systems Research Seminar in Scandinavia, P. Flensburg and C. Ihlström (Eds.), Falkenberg, Sweden, August 14-17, 2004.

Schoeman, M., and Cloete, E. "Architectural Components for the Efficient Design of Mobile Agent Systems," in Proceedings of the 2003 Annual Research Conference of the South African Institute of Computer Scientists and Information Technologists on Enablement through Technology, Fourways, South Africa, 2003, pp. 48-58.

Schwiderski-Grosche, S., and Knospe, H. "Secure Mobile Commerce," Electronics and Communication Engineering Journal (14:5), 2002, 228-238.

Senn, J. "The Emergence of M-Commerce," IEEE Computer (33:12), 2000, pp. 148-150.

Shih, G., and Shim, S. S. Y. "A Service Management Framework for M-Commerce Applications," Mobile Networks and Applications (7), 2002, pp. 199-212.

Siau, K., Lim, E., and Shen, Z. "Mobile Commerce: Promises, Challenges, and Research Agenda," Journal of Database Management (12:3), 2001, pp. 4-13.

Sklavos, N., Moldovyan, N. A., and Koufopavlou, O. "High Speed Networking Security: Design and Implementation of Two New DDP-Based Ciphers," Mobile Networks and Applications (10:2), 2005, pp. 219-231.

Smith, G. The Object-Z Specification Language, Boston: Kluwer Academic Publishers, 2000.

Smith, G. "A Formal Framework for Modeling and Analyzing Mobile Systems," in Proceedings of the $27^{\text {th }}$ Australiasian Computer Science Conference, Dunedin, New Zealand, 2004, pp. 193-202.

Smith-Berndtsson, D., and §̊ström, J. "Is There a Need for Mobile Services? Understanding the Everyday Lives of 'Ordinary' Users with Cars," in Proceedings of the $24^{\text {th }}$ Conference on Information Systems Research in Scandinavia, S. Bjørnestad, R. E. Moe, A. I. Mørch, and A. L. Opdahl (Eds.), Bergen, Norway, August 11-14, 2001, pp. 385-395.

Straub, T., and Heinemann, A. "An Anonymous Bonus Point System for Mobile Commerce Based on Word-of-Mouth Recommendation," in Proceedings of the $19^{\text {th }}$ Annual ACM Symposium on Applied Computing, Nicosia, Cyprus, March 14-17, 2004, pp. 766-773

Tang, J., Terziyan, V., and Veijalainen, J. "Distributed PIN Verification Scheme for Improving Security of Mobile Devices," Mobile Networks and Applications (8:2), 2003, pp. 159-175.

Tang, J., and Veijalainen, J. "Using Agents to Improve Security and Convenience in Mobile ECommerce," in Proceedings of the $34^{\text {th }}$ Hawaii International Conference on System Sciences, Los Alamitos, CA: IEEE Computer Society Press, 2001.

Thorstensten, B., Syversen, T., Bjørnvold, T., and Walseth, T. "Electronic Shepherd: A LowCost, Low-Bandwidth, Wireless Network System," in Proceedings of the $2^{\text {nd }}$ International Conference on Mobile Systems, Applications, and Services, Boston, MA, 2004, pp. 245-255.

Tsalgatidou, A., and Pitoura, E. "Business Models and Transactions in Mobile Electronic Commerce: Requirements and Properties," Computer Networks (37), 2001, pp. 221-236.

Van de Kar, E., Maitland, C. F., de Montalvo, U. W., and Bouwman, H. "Design Guidelines for Mobile Information and Entertainment Services," in Proceedings of the $5^{\text {th }}$ International Conference on Electronic Commerce, New' York: ACM Press, 2003.

Varshney, U., and Vetter, R. "Mobile Commerce: Framework, Applications and Networking Support," Mobile Networks and Applications (7:3), 2002, pp. 185-198.

Wang, Y., and Pang, X. "Security and Robustness Enhanced Route Structures for Mobile Agents," Mobile Networks and Applications (8:4), 2003, pp. 413-423. 
Webster, J., and Watson, R. T. "Analyzing the Past to Prepare for the Future: Writing a Literature Review," MIS Quarterly (26:2), 2002, pp. xiii-xxii.

Wei, H., and Gitlin, R. "Two-Hop-Relay Architecture For Next-Generation WWAN/WLAN Integration," IEEE Wireless Communications (11:2), 2004, pp. 24-30.

Weilenman, A. "Mobile Methodologies: Experiences from Studies of Mobile Technologies-inUse," in Proceedings of the $24^{\text {th }}$ Conference on Information Systems Research in Scandinavia, S. Bjørnestad, R. E. Moe, A. I. Mørch, and A. L. Opdahl (Eds.), Bergen, Norway, August 11-14, 2001, pp. 243-256.

Weippl, E., and Essmayr, W. "Personal Trusted Devices for Web Services: Revisiting Multilevel Security," Mobile Networks and Applications (8:2), 2003, pp. 151-157.

Wu, H., and Chuang, P. "Dynamic QoS Allocation for Multimedia Ad Hoc Wireless Networks," Mobile Networks and Applications (6:4), 2001, pp. 377-384.

$\mathrm{Xu}, \mathrm{H}$., and Teo, H. "Alleviating Consumers' Privacy Concerns in Location-Based Services: A Psychological Control Perspective," in Proceedings of the $25^{\text {th }}$ International Conference on Information Systems, R. Agarwal, L. Kirsch, and J. I. DeGross (Eds.), Washington, DC, December 12-15, 2004, pp. 793-806.

Yang, H., Ye, F., Luo, H., Lu, S., and Zhang, L. "Security in Mobile Ad Hoc Networks: Challenges and Solutions," IEEE Wireless Communications (11:1), 2004, pp. 38-47.

Yen, D. C., and Chou, D. C. "Wireless Communications: Applications and Managerial Issues," Industrial Management \& Data Systems (100:9), 2000, pp. 436-443.

Yu, O. T. W. "End-to-End Adaptive QoS Provisioning Over GPRS Wireless Mobile Network," Mobile Networks and Applications (8:3), 2003, pp. 255-67.

\section{ABOUT THE AUTHORS}

Jens Henrik Hosbond is a Ph.D. student in Information Systems at the Department of Computer Science at Aalborg University. His research focuses on the emerging discourse of mobile systems development. He is currently working with a characterization of mobile systems development with respect to its constituting elements and how it is similar or different from traditional systems development. Jens can be reached at joenne@cs.aau.dk.

Peter Axel Nielsen is an associate professor in Information Systems at the Department of Computer Science at Aalborg University. For the past several years, he has been engaged in understanding information systems development practice and the use of methodologies. His research interests include analysis and design techniques, object-orientation, and software process improvement. He is coauthor of a book on object-oriented analysis and design and a book on software process improvement. Peter can be reached at pan@cs.aau.dk. 